\section{Marine animal killing}

SIR - D.E. Sergeant is correct in claiming that work on humane killing of seals and whales is intermittent and under-financed (Nature 17 February, p.560). Sadly, this is likely to remain so while those engaged in such activities place profit margins above all other considerations.

Dr Sergeant thinks we are "passing through a period when whaling and sealing are socially unacceptable". I am not sure that is so, but I think we are passing into a period in which it is not acceptable that industries exploit living marine resources except insofar as it can be ensured, from scientific assessments, that the level of exploitation is sustainable.

The reason why those with no particular axe to grind are so upset with the Canadian Government over the "hunt" for young harp and hooded seals is that the administration of Fisheries and Oceans Canada has been so adamant in refusing to acknowledge what most scientists who have studied the data believe - that there is enormous uncertainty about the numbers of animals that remain, and about whether they have increased in numbers in recent years or declined under the quota system. In this situation any administration truly concerned with the continuing productivity of a slowly renewable resource would cut back quotas for "safety".

Dr Sergeant says that "when hunting pressure is relaxed sea mammal populations rise to near primaeval levels", so long as "we maintain their food base, and the water quality of the near-seas". But there is little empirical evidence for that assertion. The idea of "full recovery" comes essentially from running backwards population models developed from studies of depletion of whaling or sealing. Most of those simplistic models have recently been called into question, and they certainly are not reliable for predicting recovery.

The only way we could conceivably be sure of natural population increases is by direct monitoring. It is therefore deeply to be regretted that in recent years the Canadian Government has not funded any direct census of harp and hooded seals.

Dr Sergeant's assertion about recovery to primaeval levels begs the question about the food base of the seals. In the mid-1960s the fishery for capelin, on which the seals are said largely to depend, collapsed due to over-fishing. In the same period $\mathrm{Dr} \mathrm{D}$. Lavigne, working at Guelph, Ontario, showed that the "condition" of the seals had deteriorated. It is unlikely that in those conditions the survival rates of pups would have been unchanged. Since then there has been some recovery of the capelin, but the consequences of these changes for the seals have not yet been worked out.

Symposium on Marine Mammals

of the Indian Ocean,

Colombo, Sri Lanka

\section{No to protection for authors}

SIR - With regard to your response to Raymond Bradley in the 26 May issue of Nature (p.278) to the effect that you obtain copyright to journal articles "so that the authors' work can then be protected" really does not make any sense as far as the authors are concerned. As one of your authors, I can say that I have no wish to be so protected. When an author publishes an article in a scientific journal, he wishes to be referenced and discussed, not protected. I believe that the most elementary poll of your authors will show that they too do not wish to be protected by copyright, and further that their interest would be best served if their articles were not copyrighted at all.

In your reply to Professor Bradley you state that the administration of permissions for copying figures or tables from articles is burdensome for busy journals such as Nature. Why not then, just as an experiment, try for, say, 1 year the policy suggested by Professor Bradley of automatically granting permission for copying figures and tables from your journal provided proper credit is given? If something bad starts to happen, you can revert to your old policy.

Marshall Space Flight Center, Alabama, USA

\section{Scripps' foundation}

SIR - In your issue of 12 May (p.126) where you memorialize Adriano Buzzati Traverso, you describe him as a co-founder of the Scripps Institution of Oceanography.

That he was not. The institution was formally founded in 1903 and had already won an international reputation as a centre for marine science when he joined its faculty in 1952.

I suspect that what was referred to was his association with Roger Revelle when the latter started what was to become the University of California at San Diego.

WILliAM A. NIERENBERG University of California, San Diego, La Jolla, California, USA

\section{Energy shortage?}

SIR - In his report on French budgets (Nature 19 May, p.193), Robert Walgate abbreviates the CNRS special programmes (actiones thematiques programmées) to ATP. Surely, real ATP is more essential for the French molecular biology programme than this pseudo ATP!

Department of Biochemistry

J.J.A. HEFFRON University College, Cork, Ireland

\section{Stereo viewing}

SIR - This letter is prompted by $\mathrm{N}$. Michael Green's letter on stereo viewing (Nature 27 January, p.279). I, and many of my friends and colleagues, have found that stereo pictures can be viewed easily without a stereo viewer or any other such device.

The trick is to focus behind the plane of the pictures so that each of the pictures is viewed as double. The focus then needs to be adjusted so that the separation between the doubles becomes just correct to superimpose the right-hand image of the lefthand picture and the left-hand image of the right-hand picture. The line joining the pictures should be parallel to the line joining the two eyes. This can be achieved by rotating the page slightly if necessary.

The book Physics for Entertainment, written by Ya Perelman (Mir Publishers) gives a "graded course" in stereo-picture viewing through a series of stero pairs of increasing detail.

D.G. BANHATTI

Radio Astronomy Centre,

Ootacamund,

Tamil Nadu, India

\section{Sir Cyril Burt's "missing ladies"}

SIR - Alerted by W.F. Bynum's positive review ${ }^{1}$ and later the half-page advertisement ${ }^{2}$, I have now obtained Nancy Stepan's interesting book The Idea of Race in Science: Great Britain 1800-1960.

On her pages 187 and 224 , it is disconcerting indeed to find the first name Jill given to the Ms Conway whom Oliver Gillie has documented in Science $^{3}$ to be one of Sir Cyril Burt's "Missing Ladies" and about whom Gillie has reported "Conway's case is. . . curious. No one. . . knows anything ... about her . . . Jensen has given her the name Jane ... but I can find no documentary evidence for this name". Furthermore, neither the source ${ }^{4,5}$ cited by Stepan for this tale of charlatanry ${ }^{6}$ uses any name other than the J. Conway which appears only in that form throughout the Burt literature.

Certainly it shakes our confidence when author and reviewer (who is cited in the Introduction by the author in support of one of her three basic assumptions) pass over in silence such a bizarre development in a very notorious case.

Institutional Racism Program,

University of Illinois,

Urbana-Champaign, Illinois, USA

Bynum, W.F. Nature 300, 122 (1982).

Nature 20 January 1983, Reader Scrvice Card No, 45.

. Gillic, O. Science 204, 1036 (1979).

4. Hearnshaw, L.S. Cyril Burt, Psvchologist (Hodder \& Stoughton, London, 1979).

Kanin, $L$. The Science and Politics of $1 Q$ (lawrence Erlbaum Associales, Polomac, Maryland, 1974).

6. Hirsch, J. SAGE Race Relations Abstracts 6 (2), 1 (1981). 